\title{
XIVth IPSA \\ World Congress: \\ Toward a Global \\ Political Science
}

\section{August 28-September I, 1988 \\ Washington, D.C.}

Included here is a chronological summary description of all activities being held at the XIVth World Congress, including the Opening Ceremony, the Plenary Sessions, Closing Ceremony, panel sessions, council meetings, business meetings, short courses, exhibits, and registration hours. All activities will be held at the Sheraton Washington Hotel unless otherwise noted. A map of the Sheraton meeting rooms will be included in the final program.

\section{SATURDAY, AUGUST 27}

12:00 p.m. to 8:00 p.m.- Registration and Information Office

I:00 p.m. to $5: 00$ p.m.-Tourism

\section{SUNDAY, AUGUST 28}

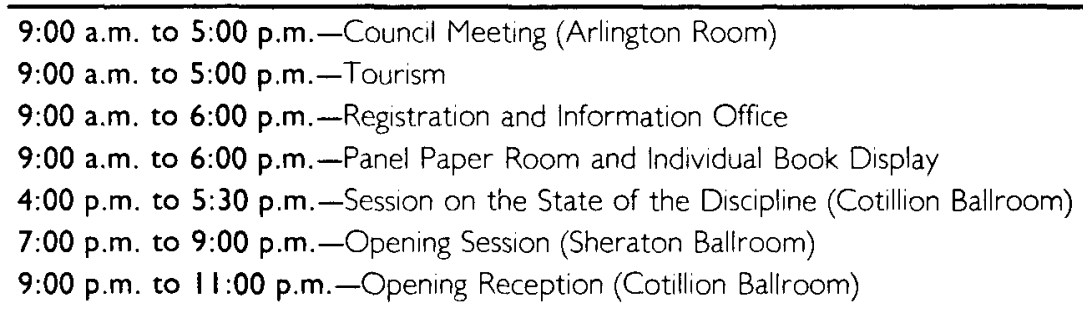

\section{MONDAY, AUGUST 29}

\section{8:00 a m. to 7:00 p.m.-Registration and Information Office}

9:00 a.m. to 6:00 p.m. - Panel Paper Room and Individual Book Display

9:30 a.m. to 12:00 p.m.-Panel Sessions

2:30 p.m. to 5:00 p.m. - Panel Sessions

5:30 p.m. to 7:30 p.m._IPSA-ISSC Plenary Session: The Globalization of the Social Science Disciplines (Sheraton Ballroom)

9:30 p.m. to midnight-Tourism

\section{TUESDAY, AUGUST 30}

8:00 a.m. to 7:00 p.m.-Registration and Information Office

9:00 a.m. to 6:00 p.m. - Panel Paper Room and Individual Book Display

9:30 a.m. to 12:00 p.m. - Panel Sessions

2:30 p.m. to 5:00 p.m.-Panel Sessions

5:30 p.m. to 7:00 p.m.-Plenary Session: AIDS

\section{WEDNESDAY, AUGUST 31}

9:00 a.m. to 6:00 p.m. - Panel Paper Room and individual Book Display

9:00 a.m. to 6:00 p.m.-APSA Sponsored Short Courses (Washington Hilton) 
9:00 a.m. to 6:00 p.m.-APSA Book Exhibit (Washington Hilton)

9:30 a.m. to 12:00 p.m. - Panel Sessions

2:00 p.m. to 4:00 p.m. - Research Institute Sessions

2:00 p.m. to 5:00 p.m.-Tourism

5:00 p.m. to 6:30 p.m. - Plenary Session: The 1988 U.S. Presidential Elections (Washington Hilton)

\section{THURSDAY, SEPTEMBER I}

8:45 a.m. to 10:30 a.m.-Panel Sessions

9:00 a.m. to 6:00 p.m.-APSA Book Exhibit (Washington Hilton)

10:45 a.m. to 12:30 p.m.-Panel Sessions

1:30 p.m. to 3:15 p.m.-Panel Sessions

3:30 p.m. to 5:30 p.m. - Panel Sessions

5:30 p.m. to 6:30 p.m.-Closing Session (Cotillion Ballroom)

8:00 p.m. to 10:30 p.m.-Plenary Session: Foreign Perspectives on U.S. Polity and Politics

(Cotillion Ballroom)

\section{SUMMARY OF PROGRAM}

Harold Jacobson, University of Michigan, Program Chair

Asher Arian, City University of New York and Tel Aviv University, and Jerzy J. Wiatr. University of Worsow, Program Vice-Chairs

SESSION ON THE STATE OF THE DISCIPLINE Sunday, 4:00 p.m.

Opening: Kenneth Waltz. University of Collfornia, Berkeley

Address: "Separate Tables: Schools and Sects in Political Science"

Gabriel A. Almond, Stanford University

OPENING SESSION

Sunday, 7:00 p.m.

Opening: John Trent, Secretory Generol, IPSA

Kinhide Mushakoji, President, IPSA

Kenneth Waltz. President, APSA

Julio Labastida M. del Campo, UNESCO

Address: To be announced

OPENING RECEPTION

Sunday, 9:00 p.m.

\section{PLENARY SESSIONS}

\section{PLENARY SESSION ONE: THE GLOBALIZATION OF THE}

SOCIAL SCIENCE DISCIPLINES

(Session organized in cooperation with the International Social Science Council)

Chair:

Kinhide Mushakoji, United Nations University, Tokyo

Papers:

"The Globalization of the International Social Science Council"

Candido Mendes, President, ISSC

"The Globalization of Political Science"

David Easton. University of Colifornia. Irvine

"The Globalization of Demography"

Massimo Livibacci, University of Florence

"How Can Social Science Become More Global?"

Karl W. Deutsch, University of Monnheim 
"The Globalization of Economics"

Victor Urquidi, Collegio de Mexico

PLENARY SESSION TWO: AIDS

Tuesday, 5:30 p.m.

Chair: $\quad$ Seymour Martin Lipset, Stanford University

Papers: "'Issues and Questions: A Research Agenda"

Andrew Marshall, Office of the Secretory of Defense, Washington, D.C.

"AIDS and the Evangelical Reaction"

Jeffrey Hadden, University of Virginia

"British Attitudes to AIDS and the Effect of the Government's Television

Advertising Campaign"

Robert Worcester, MORI, London

"German Attitudes to Aids: Change Over Time"

Renate Kocher, Institut fur Demoskopie, Allensbach

"Reactions to AIDS in the Soviet Union"

Murray Feshbach, Georgetown University

"Japanese Reactions Towards Disease and Foreigners"

Stephen Rosen, U.S. Noval War College

"A Politician Reacts"

Barney Frank, U.S. House of Representatives

PLENARY SESSION THREE: THE 1988

U.S. PRESIDENTIAL ELECTIONS

Wednesday, 5:00 p.m.

Chair: Thomas E. Mann, The Brookings Institution

Participants: Campaign Strategists for the Two Major Party Candidates

PLENARY SESSION FOUR: FOREIGN PERSPECTIVES

ON U.S. POLITY AND POLITICS ........................ Thursday, 8:00 p.m.

Chair: Kinhide Mushakoji, United Nations University. Japan

Participants: Fedor Burlatsky, Literatumaya Gazeto

Anthony King, University of Essex

Marie-France Toinet, Fondation Nationale des Sciences Politiques

CLOSING SESSION

Thursday, 5:30 p.m.

\section{MINI-PLENARY SECTIONS}

MINI-PLENARY SECTION I: POLITICAL SCIENCE METHODOLOGY

AND EPISTEMOLOGY

Convenors: Pierre Allan, Universite de Geneve

Adam Przeworski, University of Chicago

MP I.I What Has Rational Choice Brought Us?

Thursday, 1:30 p.m.

Chairs: $\quad$ Pierre Allan, Universite de Geneve

Adam Przeworski, University of Chicago

MP I.2 New Methodologies and Epistemologies in Political Science Wednesday, 9:30 a.m.

Chairs: $\quad$ Pierre Allan, Universite de Geneve

Adam Przeworski, University of Chicago

MINI-PLENARY SECTION II: THE PLURALIZATION OF POLITICAL SCIENCE

Convenors: Alan Arian, City University of New York and Tel Aviv University

Claude Ake. University of Port Harcourt 
MP II. I Title Unknown

Monday, 2:30 p.m.

Chair: $\quad$ Asher Arian, City University of New York and Tel Aviv University

MP II. 2 Title Unknown

Thursday, 10:45 a.m.

Chair:

Claude Ake, University of Port Harcourt

MINI-PLENARY SECTION III: THE SYNCHRONIC AND

DIACHRONIC

APPROACHES

Convenors: Ergun Ozbudun, Ankara University, Turkey

Guillermo O'Donnell, CEBRAP, Brazil

MP III.I The State Tradition in the Middle East and East Central Europe

Monday, 9:30 a.m.

Chair: $\quad$ Ergun Ozbudun, Ankoro University, Turkey

MP III. 2 The State Tradition in Latin America and Eastern Asia

Monday, 2:30 p.m.

Chair: $\quad$ Guillermo O'Donnell, CEBRAP, Brazil

MINI-PLENARY SECTION IV: A GLOBAL POLITICAL THEORY?

Convenors: Carole Pateman, University of Sydney

Bhikhi Parekh, University of Hull

MP IV.I Title Unknown

Thursday, 1:30 p.m.

Chair: $\quad$ Carole Pateman, University of Sydney

MP IV.2 The Extent to Which Western Political Theory

Is and $\mathrm{Can}$ Be Global Wednesday, 9:30 a.m.

Chair:

Bhikhu Parekh, University of Hull

MP IV.3 A Global Political Theory

Tuesday, 9:30 a.m.

Chair: $\quad$ To be announced

MINI-PLENARY SECTION V: COMMUNICATIONS AND

POLITICAL SCIENCE

Convenors: Itzhak Galnoor, Hebrew University of Jerusolem

Jay G. Blumler, University of Leeds, England, and University of Maryland, College Park

MP V.I Communication and the Study of Politics Thursday, 8:45 a.m.

Chair: Itzhak Galnoor, Hebrew University of Jerusolem

MP V. 2 International Communication and International Politics Thursday, 3:30 p.m.

Chair: Jay G. Blumler, University of Leeds, England, and University of Maryland, College Park

MP V.3 Language Planning and Politics

Monday, 9:30 a.m.

Chair: Brian Weinstein, Howord University and Hebrew University

MINI-PLENARY SECTION VI: THE POLICY ORIENTATION AND BEYOND

Convenors: Bjorn Wittrock, SCASS, Uppsala

Simon Schwartzman, IUPERI, Brazil

MP VI.I Advances in Comparative Policy-Oriented Research

in Political Science

Tuesday, 2:30 p.m.

Chair: $\quad$ Theda Skocpol, Harvard University 


\section{International Political Science}

MP VI.2 Theoretical Innovation in Policy-Oriented Social and Political Science

Thursday, 8:45 a.m.

Chair: $\quad$ Bjorn Wittrock, SCASS, Uppsala

\section{MINI-PLENARY SECTION VII: GLOBALIZATION AND GENDER \\ Convenors: Caroline Andrew, University of Ottowa \\ Drude Dahlerup, University of Aarhus}

MP VII.I Global and/or Regional Approaches to the Study of Women in Politics

Chair: Caroline Andrew, University of Ottowo

MP VII.2 Adding Women or Revising the Discipline? Thursday, 3:30 p.m.

Chair: $\quad$ Drude Dahlerup, University of Aarhus

MINI-PLENARY SECTION VIII: THE INSTITUTIONALIZATION OF

COMPARATIVE RESEARCH

Convenors: Seymour Martin Lipset, Stonford University

Mattei Dogan, CNRS, Poris

MP VIII. I Organized Research Efforts

Tuesday, 2:30 p.m.

Chair: $\quad$ Seymour Martin Lipset, Stanford University

MP VIII.2 Roundtable on the Institutionalization of

Comparative Research

Tuesday, 9:30 a.m.

Chair: $\quad$ Mattei Dogan, CNRS, Paris

\section{SUB-FIELD SECTIONS}

\section{SUB-FIELD I: POLITICAL PHILOSOPHY AND THOUGHT}

Convenor: Georges Lavau, Institut d'Etudes Politiques de Paris

SF I.I Title Unknown

Wednesday, 9:30 a.m.

Chair: $\quad$ Fedor Burlatsky, Academy of Sciences of the USSR

SUB-FIELD II: POLITICAL THEORY

Convenors: Russell Hardin, University of Chicago

Yasunori Sone, Keio University

SF II.I Political Theory and Public Affairs

Monday, 2:30 p.m.

Chair: Thomas Christiano, University of Texas, Austin

SF II.2 Citizenship in Industrial Societies Thursday, 10:45 a.m.

Chair: Stephen T. Holmes, University of Chicago

SF II.3 Power, Class, and Political Change: I . . . . . . . . . . . . . . . Tuesday, 9:30 a.m.

Chair: Robert E. Goodin, University of Essex

SF II.4 Power, Class, and Political Change: II

Tuesday, 2:30 p.m.

Chair: Reynolds B. Schultz, University of Chicago

SF II.5 Political Theory Around the Globe Thursday, 1:30 p.m.

Chair: Jack Knight, University of Chicogo 


\section{Schedule of IPSA 14th World Congress}

SF II.6 Toward Global Political Theory

Wednesday, 9:30 a.m.

Chair:

Charles Silver, University of Texas Law School

SUB-FIELD III: INTERNATIONAL POLITICAL ECONOMY

Convenors: Dani Wadada Nabudere, International Peoples College

Vinod Kumar Aggarwal, University of California. Berkeley

Tamas Szentes, Institute of Social Sciences. Budopest

SF III.I The International Economic System

Tuesday, 2:30 p.m.

Chair: Hasu H. Patel, University of Zimbabwe

SF III. 2 International Economic Institutions

Tuesday, 9:30 a.m

Chair: Vinod Kumar Aggarwal, University of Colifornia. Berkeley

SF III. 3 Emergent Patterns in the International Division of Labor

Monday, 9:30 a.m.

Chair: James A. Caporaso, University of Denver

SF III. 4 Prospects for a New World Economy

Wednesday, 9:30 a.m.

Chair:

Tamas Szentes, Institute of Social Sciences, Budopest

SF III.5 South-South Economic Co-operation

Monday, 2:30 p.m

Chair:

Archie W. Singham, CUNY. Brooklyn College

SF III.6 States and Markets in World Economic Restructuring

Thursday, 8:45 a.m.

Chair: Susan Strange, London School of Economics and Political Science

SUB-FIELD IV: INTERNATIONAL SECURITY ISSUES

Convenors: Joseph S. Nye, Harvard University

Georgii Shakhnazarov. Academy of Sciences of the USSR

SF IV.I Approaches to Security in the Nuclear Age

Thursday, 8:45 a.m.

Chair: Joseph S. Nye, Harvard University

SF IV.2 The Impact of Arms Transfers and Third World Arms Production . . . Tuesday, 2:30 p.m.

Chair: $\quad$ Roger E. Kanet, University of Illinois, Urbana-Champaign

SF IV.3A Security Issues in South Asia: Part I

Monday, 9:30 a.m.

Chair: $\quad$ Ram Naresh Trivedi, Ranchi University

SF IV.3B Security Issues in South Asia: Part II

Monday, 2:30 p.m.

Chair: $\quad$ Stephen P. Cohen, University of Illinois, Urbona

SF IV.4 Interdependence and Security

Thursday, 10:45 a.m.

Chair:

Alexander Nikitin, Institute of USA and Canada, Moscow

SF IV.5 Security and Independence: Problems of Stability and Development

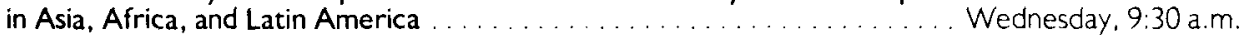

Chair: $\quad$ Alexander Chicherov, Institute of Oriental Studies, USSR

SF IV.6 European Security Problems

Tuesday, 9:30 a.m.

Chair: Max Schmidt, Instituie of International Politics and Economics of the GDR

SF IV.7 Political Economy and Security

Thursday, 1:30 p.m. 


\section{International Political Science}

Chair: $\quad$ Susan Strange, London School of Economics and Political Science

SUB-FIELD V: FORMAL MODELS OF INTERNATIONAL POLITICS

Convenors: Takashi Inoguchi, University of Tokyo

Viktor Gelovani, Acodemy of Sciences of the USSR

SF V.I Current State of Affairs in Formal Models of

International Politics

Monday, 9:30 a.m.

Chair: Takashi Inoguchi, University of Tokyo

SF V.2 Artificial Intelligence Models of Social and International Structures Thursday, 1:30 p.m.

Chair: $\quad$ Sanjoy Banerjee, San Francisco Stote University

SF V.3 Policy Relevance: Conceptions and Realities Tuesday, 9:30 a.m.

Chair: $\quad$ To be announced

SF V.4 Global Modelling and Models of Arms Race and Disarmament . . . . . Thursday, 10:45 a.m. Chair: $\quad$ To be announced

SF V.5 Game-Theoretic Models of International Politics Wednesday, 9:30 a.m.

Chair: Steven J. Brams, New York University

SUB-FIELD VI: COMPARATIVE NATIONAL INSTITUTIONS

Convenors: Jerzy J. Wiatr, University of Warsow

Ezra Suleiman, Princeton University

SF VI.I Comparing National Institutions: Theoretical Approaches

Wednesday, 9:30 a.m.

Chair: $\quad$ Ezra Suleiman, Princeton University

SF VI.2 Legislatures

Tuesday, 2:30 p.m.

Chair: $\quad$ R. B. Jain, University of Delhi

SF VI.3 Executive Leadership Thursday, 1:30 p.m.

Chair: Anthony King, University of Essex

SF VI.4 Courts and Public Policies Monday, 9:30 a.m.

Chair: Najdan Pasic, University of Belgrode

SF VI.5 Civil and Military Institutions Thursday, 3:30 p.m.

Chair: $\quad$ Jerzy J. Wiatr, University of Worsow

SUB-FIELD VII: COMPARATIVE NATIONAL POLITICAL PROCESSES

Convenors: Karl-Heinz Roder, Academy of Sciences of the GDR

Juan Linz, Yole University

SF VII.I Political Parties Monday, 9:30 a.m.

Chair: $\quad$ Scott Mainwaring, University of Notre Dame

SF VII.2A Interest Representation: Changes and Continuities in the Representation and Mobilization of Workers Thursday, 1:30 p.m.

Chair: Robert Fishman, Harvard University

SF VII.2B Interest Representation: New Democracies Thursday, 3:30 p.m. 


\section{Schedule of IPSA 14th World Congress}

Chair: $\quad$ Robert Fishman, Harvard University

SF VII. 3 Crisis and Political Instability Thursday, 10:45 a.m.

Chairs: $\quad$ Ekhart Zimmermann, Universitot der Bundeswehr Munchen

C. P. Bhambhri, Jawahorlal Nehru University

SF VII.4A Typologies of Contemporary Political Systems: Part I

Tuesday, 9:30 a.m.

Chairs: $\quad$ Anton Bebler, University Edvard Kardelj

Okwudiba Nnoli, University of Nigeria

SF VII.4B Typologies of Contemporary Political Systems: Part II

Tuesday, 2:30 p.m.

Chairs: $\quad$ Anton Bebler, University Edvard Kardelj

Okwudiba Nnoli, University of Nigeria

SF VII.5 Political Processes in Federal Political Systems

Wednesday, 9:30 a.m.

Chair: $\quad$ Karl H. Cerny, Georgetown University

SUB-FIELD VIII: COMPARATIVE POLITICAL ATTITUDES AND

PARTICIPATION

Convenor: $\quad$ Ada W. Finifter, Michigan State University

SF VIII.I Group Differences in Political Attitudes Thursday, 8:45 a.m.

Chair: Paul R. Abramson, Michigan Stote University

SF VIII.2 Political Culture and Political Participation Monday, 9:30 a.m.

Chair: William S. Stewart, California State University, Chico

SF VIII.3 Political Socialization for Citizenship

Wednesday, 9:30 a.m.

Chair: Roberta Sigel, Rutgers University

SF VIll.4 Political Socialization ......................... Thursday, 10:45 a.m.

Chair: $\quad$ Eileen Wormald, University of Papua New Guinea

SF VIII.5 Discussion of Political Representation in France

by Philip E. Converse and Roy Pierce

Thursday, 1:30 p.m.

Chair: $\quad$ Ada W. Finifter, Michigan State University

SF VIII.6 Political Participation and Reforms of Government: Part I

Monday, 2:30 p.m.

Chair: Josef Blahoz, Czechoslovak Acodemy of Sciences

SF VIII.7 Political Attitudes and Political Involvement

Tuesday, 9:30 a.m.

Chair: Warren E. Miller, Arizona State University

SF VIII.8 Manipulation of Public Opinion

Wednesday, 9:30 a.m.

Chair: Michael Margolis, University of Pittsburgh

SF VIII. 9 Comparative Ideological Structures

Thursday, 10:45 a.m.

Chair: $\quad$ Fred Eidlin, University of Guelph

SF VIII. 10 Immigration and Politics

Tuesday, 2:30 p.m.

Chair: Michael Peter Smith, University of California, Davis

SF VIII. I I Political Participation and Reforms of Government: Part II . . . . . . Thursday, 3:30 p.m.

Chair: $\quad$ Sirkka Sinkkonen, Academy of Finland 


\section{SUB-FIELD IX: COMPARATIVE SUB-NATIONAL STUDIES}

Convenors: Francesco Kjellberg, University of Oslo

Renata Siemienska, University of Worsow

SF IX.I The Concept of Local Government: Theoretical Perspectives . . . Wednesday, 9:30 a.m. Chair: Henry Teune, University of Pennsylvania

SF IX. 2 Selection Process of Local Leaders Thursday, 8:45 a.m.

Chair: $\quad$ Chung-Si Ahn, Seoul National University

SF IX.3 Problem Perception and Value Priorities of Local Leaders . . . . . . . Thursday, 3:30 p.m.

Chair: Renata Siemienska, University of Worsow

SF IX.4 Variations in the Role of Local Government:

Functions and Performance Monday, 2:30 p.m.

Chair: $\quad$ Francesco Kjellberg, University of Osto

SF IX.5 Local Autonomy and Central Steering: Recent Experiences in

Developed and Developing Nations Tuesday, 2:30 p.m.

Chair:

Mae C. King-Akesode, University of Benin

SUB-FIELD $X$ : COMPARATIVE PUBLIC ADMINISTRATION AND POLICY

Convenor: Ivan Nedev, Embassy of Bulgaria, Spain

SF X.I Methodological Aspects of Comparative Analysis of

Public Administration and Policy Tuesday, 9:30 a.m.

Chair:

Nora Ananieva, Buigaria

SF X.2 Public Administration in Different Political Systems:

Separation of Powers, Democratic Institutions, Etc. Thursday, 1:30 p.m.

Chair: $\quad$ Seymour V. Wilson. Corleton University

SF X.3 The Individual and Public Administration:

Social Relations, Behavior, Professionalism Wednesday, 9:30 a.m.

Chair: Ulrich Kloeti, University of Zurich

SF X.4 The Information Revolution and Public Administration ............ Monday, 9:30 a.m.

Chair: Mintscho Semov, Sofia University

SF X.5 Public Administration and Global Problems Tuesday, 2:30 p.m.

Chair: Marvin S. Soroos, North Carolina State University

\section{RESEARCH COMMITTEES}

\section{RESEARCH COMMITTEE I: CONCEPTUAL AND TERMINOLOGICAL} ANALYSIS (COCTA)

Convenors: Jan-Erik Lane, University of Umea

Jacques Gerstle, Universite de Potiers

RC 1.1 Epistemological and Theoretical Foundations of Conceptual Analysis Monday, 2:30 p.m.

Chair: $\quad$ Judith Gillespie, University of Minnesota, Duluth

RC I.2 Problems of Ethnic Terminology Monday, 9:30 a.m. 
Chair: Dennis L. Thompson, Brigham Young University

RC 1.3 State, Periphery and Human Betterment Tuesday, 2:30 p.m.

Chair: Jan-Erik Lane, University of Umeo

\section{RESEARCH COMMITTEE 2: POLITICAL ELITES}

Convenors: Mattei Dogan, CNRS, Paris

Dwaine " arvick, University of California, Los Angeles

RC 2.I Charisma, Idolatry, and Plebiscitarian Leadership Monday, 9:30 a.m.

Chair: $\quad$ Mattei Dogan, CNRS, Poris

RC 2.2 Party Activists as Mid Elites Thursday, 10:45 a.m.

Chair: $\quad$ Samuel J. Eldersveld, University of Michigan

RC 2.3 Theories of Elites and Political Change Monday, 2:30 p.m.

Chair: John Higley, University of Texos, Austin

\section{RESEARCH COMMITTEE 3: EUROPEAN UNIFICATION}

Convenor: Ghita lonescu, London School of Economics and Political Science

RC 3.I The European Community in the World . . Tuesday, 9:30 a.m.

Chair: Ghita lonescu, London School of Economics and Political Science

RC 3.2 Research on European Integration Monday, 9:30 a.m.

Chair: Emile Noel, European University Institute, Florence

RC 3.3 The Concept of Integration Seen from East and West Thursday, 1:30 p.m.

Chair: Klaus von Beyme, University of Heidelberg

RESEARCH COMMITTEE 5: COMPARATIVE STUDIES ON

LOCAL GOVERNMENT AND POLITICS

Convenors: Bruno Dente, Bologno, Itoly

Hellmut Wollmann, Freie Universitat Berlin

RC 5.I Towards a "Re-Municipalization" of the Welfare State? Thursday, 8:45 a.m.

Chair: Hellmut Wollmann. Freie Universitot Berlin

RC 5.2 The Changing Function of Local Government in Third World Countries Thursday, 3:30 p.m.

Chairs: $\quad$ Philip Mawhood, University of Birmingham

Dhirendra Vajpeyi, University of Northern lowa

\section{RESEARCH COMMITTEE 6: POLITICAL SOCIOLOGY}

Convenor: Derek Urwin, University of Warwick

RC 6.I American Exceptionalism Wednesday, 9:30 a.m.

Chairs: Seymour Martin Lipset, Stanford University Byron Shafer, Nuffield College

RC 6.2 Welfare State or Prosperity State?

A European/American Contrast Tuesday, 2:30 p.m.

Chairs: Jens Alber, Max-Planck-Institut fur Gesellschaftsforschung Stein Kuhnle, University of Bergen 
RC 6: Subcommittee: Workshop on Parties and Elections Monday, 12:00 p.m.

RESEARCH COMMITTEE 7: QUANTITATIVE AND MATHEMATICAL APPROACHES TO POLITICS

Convenor: Urs Luterbacher, Institute for International Studies, Geneva

RC 7.I Problems on Modeling International Cooperation Thursday, 10:45 a.m.

Chair: Urs Luterbacher, Institute for International Studies, Geneva

\section{RESEARCH COMMITTEE 8: LEGISLATIVE SPECIALISTS}

Convenors: Allan Kornberg, Duke University

RC 8.I Comparative Structures and Processes of Parliaments Monday, 9:30 a.m.

Chair: David M. Otson, University of North Carolina, Greensboro

RC 8.2 The Comparative Study of Parliamentarians Tuesday, 9:30 a.m.

Chair: William Mishler, University of South Carolina.

RESEARCH COMMITTEE 9: COMPARATIVE JUDICIAL STUDIES

Convenor: C. Neal Tate, North Texas State University

RC 9.1 Judging in Europe: Cross-National and International Perspectives. Tuesday, 9:30 a.m.

Chair: $\quad$ Samuel Krislov, University of Minnesota

RC 9.2 Judiciaries and Dispute Resolution in the Third World . Monday, 2:30 p.m.

Chair: $\quad$ Edward Goldberg, California State University, Los Angeles

\section{RESEARCH COMMITTEE II: SCIENCE AND POLITICS}

Convenor: Bernard Crousse, Fondation Universitaire Luxembourgeoise

RC II.I Science, Its Ethics and the Political Field Tuesday, 9:30 a.m. Chair: Rejean Landry, Universite Loval

RC II.2 Ethical Problems and Science Policies Thursday, 1:30 p.m.

Chair: Luc Rouban, Centre national de la recherche scientifique

\section{RESEARCH COMMITTEE 12: BIOLOGY AND POLITICS}

Convenor: Albert Somit, Southern Illinois University

RC I 2.1 Politics and AIDS: Towards a National Policy Thursday, 10:45 a.m.

Chair: $\quad$ Robert H. Blank, Northern Illinois University

RC 1 2.2 Physical and Biochemical Factors in Political Activity Wednesday, 9:30 a.m. Chair: Albert Somit, Southern Illinois University

RC 12.3 Sexual Differences in Global Politics Thursday, 3:30 p.m.

Chair: Meredith Watts, University of Wisconsin, Milwaukee

RESEARCH COMMITTEE 13: DEVELOPMENT AND POLITICAL SYSTEMS

Convenor: Candido Mendes, Sociedade Brasileira de Instrucao 


\section{Schedule of IPSA 14th World Congress}

RC 13.I The Strategies of Democratization Monday, 9:30 a.m.

Chair:

Dirk Berg-Schlosser, Philipps Universitoet Morburg

RESEARCH COMMITTEE 14: POLITICS AND ETHNICITY

Convenors: Dov Ronen, Harvard University

Dennis L. Thompson, Brigham Young University

RC 14.1 Problems of Ethnic Terminology Monday, 9:30 a.m.

Chair: Dennis L. Thompson, Brigham Young University

RC 14.2 Center/Periphery Relations Thursday, 8:45 a.m.

Chair: $\quad$ Donald Rothchild, University of California, Dovis

RESEARCH COMMITTEE 15: POLITICAL GEOGRAPHY

Convenors: Jean Gottmann, Oxford, England

Jean A. Laponce, University of British Columbia

RC 15.1 Political Geography and Religious Factors: Part I

Monday, 2:30 p.m.

Chair:

Calogero Muscara, Rome, Itoly

RC I5.2 Political Geography and Religious Factors: Part II Tuesday, 2:30 p.m.

Chair: Jean Gottmann, Oxford, England

\section{RESEARCH COMMITTEE 16: SOCIO-POLITICAL PLURALISM}

Convenor: H. G. Thorburn, Queen's University

RC 16.1 Theories of Pluralism Thursday, 3:30 p.m.

Chair: $\quad$ Luigi Graziano, University of Turin

RC 16.2 Pluralism as a Paradigm of Social Science? Thursday, 8:45 a.m.

Chair: $\quad$ H. G. Thorburn, Queen's University

RC 16.3 Pluralism, Corporatism, What? Wednesday, 9:30 a.m.

Chair: $\quad$ Thomas $O$. Hueglin, Wilfrid Laurier University

RESEARCH COMMITTEE 17: THE EMERGING INTERNATIONAL ECONOMIC ORDER

Convenors: Dusan Sidjanski, University of Geneva

Robert S. Walters, University of Pittsburgh

RC 17.I State Structures and the Changing World Economy Thursday, 10:45 a.m.

Chair: Dusan Sidjanski, University of Geneva

RC 17.2 Bargaining, Markets and the State in Structural Change Monday, 2:30 p.m.

Chair: Robert S. Walters, University of Pittsburgh

RC 17.3 States and Markets in World Economic Restructuring Thursday, 8:45 a.m.

Chair: Susan Strange, London School of Economics and Political Science

RESEARCH COMMITTEE 18: ASIAN POLITICAL STUDIES

Convenor: Teh-Kuang Chang, Ball State University

RC 18.I The Democratization in Asia Monday, 9:30 a.m. 


\section{International Political Science}

Chair: $\quad$ Teh-Kuang Chang, Ball State University

RC 18.2 The New Development of Political Science in Asia Thursday, 8:45 a.m.

Chair: Shu-Liang Yeh, Kong Kong Shue Yang College

RC 18.3 Roundtable on the Political Development and Social Change in the Pacific-Rim States Thursday, 3:30 p.m.

Chair: Gotterfried-Karl Kindermann, University of Munich

\section{RESEARCH COMMITTEE 19: SEX ROLES AND POLITICS}

Convenor: Hem Lata Swarup, Konpur University

RC 19.1 Women and the Politics of Religion Monday, 9:30 a.m.

Chairs: Hem Lata Swarup, Kanput University

Greeta Lomjee, International Development Consultant, Canoda

RC 19.2 A Global Concept of Patriarchy? Tuesday, 9:30 a.m.

Chair: Drude Bahlerup, University of Aarhus

KC 19.3 Crossnational Comparisons of Women's Political Activities:

Theories, Methods and Findings Monday, 2:30 p.m.

Chair: Barbara J. Nelson, University of Minnesoto

\section{RESEARCH COMMITTEE 20: POLITICAL FINANCE} AND POLITICAL CORRUPTION

Convenors: Michael Pinto-Duschinsky, Brunel University

Herbert E. Alexander, University of Southern California

RC 20.I Political Finance Monday, 2:30 p.m.

Chair: Herbert E. Alexander, University of Southern Colifornia

RC 20.2 Political Corruption Tuesday, 2:30 p.m.

Chair: Michael Pinto-Duschinsky, Brunel University

RC 20: Business Meeting Tuesday, 12:00 p.m.

\section{RESEARCH COMMITTEE 2I: POLITICAL EDUCATION}

Convenors: Bernhard Claussen, University of Hamburg. Germany

Suna Kili, Bogazici University, Turkey

RC 21.1 Perspectives of Globalization and Internationalization of Political Education and Political Socialization Tuesday, 2:30 p.m.

Chair: Bernhard Claussen, University of Homburg, Germany

RC 21.1 Comparative Political Education Research:

Aspects of Cross Cultural Studies Thursday, 8:45 a.m. Chair:

Suna Kill,Bogazici University, Turkey

RC 21.3 Political Education Research as a Topic of Global Political Science Monday, 2:30 p.m.

Chair:

Carlos Alberto Torres, FLDS, Mexico

\section{RESEARCH COMMITTEE 22: GLOBAL COMMUNICATIONS}

Convenor: Elizabeth C. Hanson, University of Connecticut 
RC 22.I Competition and Cooperation in the Global Information Economy Thursday, 10:45 a.m

Chair: $\quad$ William J. Drake, University of California, San Diego

RC 22.2 Images and International Communication: Using the News Wednesday, 9:30 a.m.

Chair: $\quad$ Elizabeth $\mathrm{C}$. Hanson, University of Connecticut

RESEARCH COMMITTEE 23: POLITICAL SUPPORT AND ALIENATION

Convenor: Kristen Renwick Monroe, University of Californio, Irvine

RC 23.I Political Support: A Comparative Perspective Tuesday, 9:30 a.m.

Chair: $\quad$ Kristen Renwick Monroe, University of California, Irvine

RC 23.2 Title Unknown Thursday, 1:30 p.m.

Chair: $\quad$ Rudolf Wildenmann, Universitaet Mannheim

RESEARCH COMMITTEE 24: ARMED FORCES AND SOCIETY

Convenor: Sam C. Sarkesian, Loyola University of Chicago

RC 24.I Civil-Military Relations: A Re-Examination of Theories and Models Thursday, 10:45 a.m.

Chairs: $\quad$ Tunde Odetola, Obafemi Awolowa University

Philip J. Briggs, East Stroudsburg University

RC 24.2 Civil-Military Relations: Case Studies I Thursday, 1:30 p.m.

Chair: Detlef Bald, Sozialwissenschaftliches Institut Der Bundeswehr

RC 24.3 Civil-Military Relations: Case Studies II Monday, 9:30 a.m. Chair: $\quad$ Augusto Varas, FLASCO, Chile

RESEARCH COMMITTEE 25: MARXIST POLITICAL THOUGHT

Convenor: Georgii Shakhnazarov, Soviet Political Science Association

RC 25.I Political Violence and Non-Violence in the Perspective of History Wednesday, 9:30 a.m.

Chair: Herve Fuget, Quebec, Canada

RC 25.2 Violence and Non-Violence: Theoretical and

Methodological Approaches in Political Science Monday, 2:30 p.m.

Chair: Gyorgy Szoboslai, Hungarian Political Science Association

\section{RESEARCH COMMITTEE 26: HUMAN RIGHTS}

Convenor: David P. Forsythe, University of Nebraska, Lincoln

RC 26.I Human Rights and Political Science as a Global Discipline Thursday, 3:30 p.m.

Chair: $\quad$ David P. Forsythe, University of Nebraska, Lincoln

RC 26.2 Human Rights in a North-South Framework ............. Tuesday, 9:30 a.m. Chair: $\quad$ Peter R. Baehr, University of Leiden

RC 26.3 Human Rights in an East-West Framework Thursday, 10:45 a.m.

Chair: Jack Donnelly, University of North Corolino 


\section{RESEARCH COMMITTEE 27 STRUCTURE AND ORGANIZATION OF GOVERNMENT}

Convenor: B. Guy Peters, University of Pittsburgh

RC 27.I Contrasting State Tradition Tuesday, 2:30 p.m.

Chair: Olof Ruin, University of Stockholm

RC 27.2 Title Unknown Wednesday, 9:30 a.m.

Chair: $\quad$ B. Guy Peters, University of Pittsburgh

RC 27: Business Meeting Tuesday, 5:00 p.m.

\section{RESEARCH COMMITTEE 28: COMPARATIVE FEDERATION} AND FEDERALISM

Convenors: Lloyd Brown-John, University of Windsor Frank Delmartino, University of Leuven Gerhard Fuchs, Universitoet Munchen

RC 28.1 Comparative Federalism and the Delivery of Public Policies Thursday, 3:30 p.m.

Chair: Frank Delmartino, University of Leuven

RC 28.2 Communication Policies in Federal Political Systems Tuesday, 2:30 p.m. Chair: $\quad$ Alain Gagnon, Corleton University

RC 28.3 Federal-Type Solutions in Non-Federal States Thursday, 8:45 a.m. Chair: Lloyd Brown-John, University of Windsor

\section{RESEARCH COMMITTEE 29: PSYCHO-POLITICS}

Convenor: Elizabeth W. Marvick, University of Californio, Los Angeles

RC 29.1 World Leaders: Psychopolitical Analyses Tuesday, 2:30 p.m.

Chair: $\quad$ Fred I. Greenstein, Princeton University

RC 29.2 Continuities in Psychopolitics: Using the Work of

Lasswell and Leites Thursday, 8:45 a.m.

Chair: Gabriel A. Almond, Stanford University

\section{RESEARCH COMMITTEE 30:F COMPARATIVE PUBLIC OPINION}

Convenor: Frederick C. Turner, University of Connecticut

RC 30.1 Attitudes to America, Americans and American Foreign and Defence Policy Abroad: The Empirical Evidence Monday, 9:30 a.m.

Chair: $\quad$ Robert M. Worcester, MORI, London

RC 30.2 Comparative Public Opinion and the Transition to

Democracy Thursday, 8:45 a.m.

Chair:

Carlos R. Miranda, University of Tampa

\section{RESEARCH COMMITTEE 31: POLITICAL PHILOSOPHY}

Convenor: Alan Gilbert, Princeton University

RC 31.I Political Practice and the Nature of Persons Thursday, 3:30 p.m.

Chair: Ken Minogue, London School of Economics and Political Science 


\section{Schedule of IPSA 14th World Congress}

RC 31.2 Reason, History and Political Judgement

Thursday, 1:30 p.m.

Chair: Benjamin R. Barber, Rutgers University

\section{STUDY GROUPS}

\section{STUDY GROUP 6: TECHNOLOGY AND DEVELOPMENT}

Convenor: O.P. Dwivedi, University of Guelph

SH 6.1 Title Unknown Monday, 2:30 p.m.

Chairs: Karan Singh, New Delhi, India

lqbal Narain, Indian Council of Social Science Research

STUDY GROUP I I: COMPARATIVE SOCIOLOGY OF POLITICAL SCIENCE

Convenor: Michael Stein, MCMaster University

SG II.I The Impact of the Political Context on the Development

of Political Science in Different Societies Tuesday, 9:30 a.m.

Chairs: Michael Stein. McMaster University

William Andrews, SUNY at Brockport

STUDY GROUP 12: REPRESSION AND REPRESENTATION:

CONVERGENT TRENDS BETWEEN LATIN AMERICA AND EUROPE

Convenor: Alessandro Pizzorno, Harvard University

SG I2.I Title Unknown Thursday, 1:30 p.m.

Chair: $\quad$ To be announced

STUDY GROUP 14: PUBLIC POLICY ANALYSIS

Convenor: Richard I. Hofferbert, SUNY at Binghamton

SG I4.I Title Unknown Tuesday, 2:30 p.m.

Chair: Guenther F. Schaefer, European Institute of Public Administration, The Netherlands

SG 14.2 Policy and Democracy in Developing Countries Thursday, 1:30 p.m.

Chair: Richard I. Hofferbert, SUNY at Binghamton

\section{STUDY GROUP 16: RETHINKING IN POLITICAL DEVELOPMENT}

Convenor: A. H. Somjee, Simon Fraser University

SG 16.1 Explorations in Development Theory Tuesday, 2:30 p.m

Chair:

A. H. Somjee, Simon Fraser University

\section{STUDY GROUP 17: POLITICAL POWER}

Convenor: David A. Baldwin, Columbia University

SG 17.1 Power Analysis Monday, 2:30 p.m

Chair: David A. Baldwin, Columbia University

\section{STUDY GROUP 18: THEORIES OF THE STATE}

Convenor: Karl-Heinz Roder, Acodemy of Sciences of the GDR

SG 18.I Democratic Theory and Democratic Realities Today: Part I Thursday, 8:45 a.m. 


\section{International Political Science}

Chair: Aaron T. Gana, University of jos

SG 18.2 Democratic Theory and Democratic Realities Today: Part II ...... Thursday, 3:30 p.m.

Chair: Marcos Kaplan. Ciudad Universitario

STUDY GROUP 19: COMPARATIVE HEALTH POLICY

Convenor: Christa Altenstetter, CUNY Groduote Center

SG 19.1 From Rhetoric to Reality: Medical Care Policies

Under Conservative Governments

Monday, 2:30 p.m.

Chair: $\quad$ Stuart C. Haywood, Health Services Monagement Center

SG 19.2 Political Science and Health Policy: The State of the Art Monday, 9:30 a.m.

Chair: Christa Altenstetter, CUNY Graduate Center

SG 19: Business Meeting

Tuesday, 12:00 p.m.

STUDY GROUP 22: POLITICS AND BUSINESS

Convenor: Robert J. Jackson, Corleton University

SG 22.I Politics and Business in Comparative Perspective Thursday, 3:30 p.m.

Chair: Desmond Hickie, Teesside Polytechnic

SG 22: Business Meeting Wednesday, 12:00 p.m.

STUDY GROUP 23: CONSTITUTION MAKING AS A POLITICAL PROCESS

Convenor: Ram Nash Trivedi, Ranchi University

SG 23.I Constitution Making as a Political Process Thursday, 10:45 a.m.

Chair: Ram Nash Trivedi, Ronchi University

\section{STUDY GROUP 24: COMPARATIVE REPRESENTATION AND \\ ELECTORAL SYSTEMS}

Convenors: Lawrence D. Longley, Lowrence University

Carol Cassel, University of Alaboma

SG 24.I Comparative Representation and Electoral Systems

Tuesday, 2:30 p.m.

Chair: $\quad$ Lawrence D. Longley, Lawrence University

SG 24.2 Electoral Systems in Industrial Democracies Tuesday, 9:30 a.m.

Chair:

Carol Cassel, University of Alabama

SG 24.3 Electoral Systems in Third World Democracies Wednesday, 9:30 a.m.

Chair: Ernie Chaples, University of Sydney

SG 24: Business Meeting Tuesday, 5:00 p.m.

\section{STUDY GROUP 25: RELIGION AND POLITICS}

Convenor: C. Frederick Stoerker, City University of New York

SG 25.I Religion and the State ........................ Tuesday, 9:30 a.m. Chair: $\quad$ C. Frederick Stoerker, City University of New York

SG 25.2 Religion and Public Policy Wednesday, 9:30 a.m. 
Chair: George Moyser, University of Manchester

SG 25.3 Religion and Mass Politics Thursday, 10:45 a.m.

Chair: $\quad$ Peter W. Sperlich, University of California, Berkeley

STUDY GROUP 26: POLICIES, INSTITUTIONS,

PERFORMANCE AND EVALUATION

Convenor: Elinor Ostrom, Indiana University

SG 26. I Title Unknown Wednesday, 9:30 a.m.

Chair: Vincent Ostrom, Indiana University

SG 26: Business Meeting Wednesday, 12:00 p.m.

STUDY GROUP 27: PUBLIC BUREAUCRACIES IN

DEVELOPING SOCIETIES

Convenors: R. B. Jain, University of Delhi

Oscar Oszlack, Buenos Aires, Argentina

SG 27.I Bureaucracy, Politics and Policy Development in the Developing Societies Thursday, |:30 p.m.

Chair: Oscar Oszlak, Buenos Aires, Argentina

SG 27.2 Bureaucracy in a Situation of Accelerating

Socio-Political Change in Developing Societies Thursday, 8:45 a.m.

Chair: Henry Habib, Concordia University

STUDY GROUP 28: EXECUTIVE STRUCTURES AND ROLES

IN CONTEMPORARY GOVERNMENT

Convenor: Albert Johnson, Madurai Kamaraj University

SG 28.1 Causes for and Consequences of Executive Dominance:

A World Focus Tuesday, 9:30 a.m.

Chair: Albert Johnson, Madurai Kamaraj University

\section{STUDY GROUP 29: MILITARY RULE AND DEMOCRATIZATION}

IN THE THIRD WORLD

Convenor: Dani W. Nabudere, International Peoples' College

SG 29.I Title Unknown Monday, 9:30 a.m.

Chair: $\quad$ Yash Tandon, Harare, Zimbabwe

STUDY GROUP 30: WOMEN, POLITICS AND DEVELOPMENT

Convenor: Najma Chowdhury, University of Dhaka

SG 30.I Women, Politics and Development: Framework for Cross-Cultural Analysis Tuesday, 9:30 a.m.

Chair: Margherita Rendel, University of London

\section{SPECIAL SESSIONS}

SS I.I Roundtable on Geopolitics and Civilizations: Part I Monday, 9:30 a.m. Chair: Anouar Abdel-Malek, CNRS, Paris

SS I.2 Roundtable on Geopolitics and Civilizations: Part II Monday, 2:30 p.m. 


\section{International Political Science}

SS 2. Discourse and Public Policy Thursday, 3:30 p.m.

Chair: Hayward R. Alker, Jr., Massochusetts institute of Technology

SS 3. Classification and Typologies of Contemporary

Political Systems Tuesday, 2:30 p.m.

Chair:

Anton Bebler, Univerza Edvarda Kardelja

SS 4. Institution-Building in China: Political Reform in a

Socialist State Thursday, 8:45 a.m.

Chair:

Robert E. Bedeski, Carleton University

SS 5. Participatory Democracy and Self-Management Thursday, 1:30 p.m.

Chair: $\quad$ Erikki Berndtson, University of Helsinki

SS 6. Social Scientists, Politics and Public Policy Thursday, 1:30 p.m.

Chairs: $\quad$ Stephen Brooks, University of Windsor

Alain Gagnon, Corleton University

SS 7. Implications of Postmaterialism as a Theory of Modernization Thursday, 10:45 a.m.

Chair: Donald J. Calista, Morist College

SS 9.1 The Movement of the Sixties Revisited: Student Protest, Social Movements, Crises Monday, 9:30 a.m.

Chair: Michel Dobry, Universite de Paris X-Nanterre

SS 9.2 The Movement of the Sixties Revisited: Reflections, Reclassifications, Reconversions Monday, 2:30 p.m.

Chair: $\quad$ Yolande Cohen, Universite de Quebec, Montreal

SS 10. Women's Careers and Women's Policies:

A Cross-Cultural Research Experiment Thursday, 8:45 a.m.

Chairs: Jeanne-Marie Col, Sangamon State University Niroj Sinha, University of Patna

SS I2. Political Risk Analysis Thursday, 1:30 p.m.

Chair: $\quad$ Umberto Gori, Istituto di Scienza Politica, Italy

SS 13.1 Divergences and Convergences in Global World Modeling

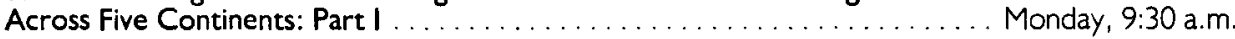

Chair: Harold Guetzkow, Northwestern University

SS 13.2 Divergences and Convergences in Global World Modeling

Across Five Continents: Part II . . . . . . . . . . . . . . . . . . . . . Monday, 2:30 p.m.

Chair: Harold Guetzkow, Northwestern University

SS 14.I State Policies on Techno-Industrial Innovation and Unintended Consequences Tuesday, 2:30 p.m.

Chairs: $\quad$ Ulich Hilpert, Free University of Berlin Wolfgang Fach, University of Constance

SS 14.2 Unintended Consequences of Fiscal Policy Actions Thursday, 3:30 p.m.

Chairs: Gerd-Michael Hellstern, Free University of Berlin Terry N. Clark, University of Chicago 


\section{Schedule of IPSA 14th World Congress}

Chair: Ushakar Jha, L. N. Mithilo University

SS 16. Progress at the Borders of Social Sciences

Wednesday, 9:30 a.m.

Chair: Ali Kazancigil, UNESCO, Paris

SS 17. Intellectuals and the State

Thursday, 3:30 p.m.

Chair: Michael Keren, Tel-Aviv University

SS 18. Nuclear Deterrence Theory: A National Perspective

Tuesday, 9:30 a.m.

Chairs: $\quad$ Edward A. Kolodziej, University of Illinois

Patrick Morgan. Woshington State University

SS 20. Political Scandal in Comparative Perspective Wednesday, 9:30 a.m.

Chairs: $\quad$ Andrei S. Markovits and Mark Silverstein, Boston University

SS 2.I Roundtable on Comparative Presidentialism Monday, 2:30 p.m.

Chair: $\quad$ Fred W. Riggs, University of Hawaii, Manoa

SS 21.2 Roundtable on Political Activist Research Tuesday, 9:30 a.m.

Chair: $\quad$ Dwaine Marvick, University of Colifornia, Los Angeles

SS 23. The Patron State: Government and the Arts in a

Comparative Perspective Thursday, 8:45 a.m.

Chair:

John Meisel, Queen's University

SS 24. The Significance of Social Movements for Social Change and the Future of the World Thursday, 8:45 a.m.

Convenor: Lester Milbrath, SUNY at Buffolo

Chair: Joan Roelofs, Keene Stote College

SS 25. Evolution of Political Science in the Arabic World Tuesday, 2:30 p.m.

Chair: Jari Mohammed, University of Bordeaux 1

SS 26. Political Reform in European Socialist Countries Thursday, 10:45 a.m.

Chair: Czeslaw Mojsiewicz, Adam Mickiewicz University

SS 27. The Society for Greek Political Thought Thursday, 8:45 a.m.

Convenor: Clifford Orwin, University of Toronto

Chair: Kent Moors, Duquesne University

SS 28. New Issue Parties and New Conflict Dimensions in Party

Systems: An International Comparison Thursday, 3:30 p.m.

Chair: $\quad$ Ferdinand Muller-Rommel, University of Luneburg

SS 29. Global Policy Studies Monday, 9:30 a.m.

Chair: $\quad$ Stuart S. Nagel, University of Illinois, Urbana

SS 30. How the Social Sciences Have Viewed African Problems Thursday, 8:45 a.m.

Chair: Helmy Sharawi, African Association of Political Science

SS 3I. From National to Global Models of Public Policy:

The American Experience in Comparative Perspective Thursday, 8:45 a.m.

Chair:

Richard Rose, University of Strathdyde 
SS 32. Micro Sources of Macro Global Change Thursday, 1:30 p.m.

Chair: James N. Rosenau, University of Southern California

SS 33. Ethnic Violence: Causes, Consequences and Remedies Monday, 2:30 p.m. Chair:

K. P. Singh, Kasturba Institute of Rural Studies

SS 34. Roundtable on Global Norms and Rigorous Methods in

Peace Research Tuesday, 9:30 a.m.

Chair:

J. David Singer, University of Michigan

SS 35. Transnational Capitalism, Socialism, and

Development in the Late Twentieth Century Thursday, 3:30 p.m.

Chairs: $\quad$ Richard L. Sklar, University of California, Los Angeles

David G. Becker, Dortmouth College

SS 36. Lay Adjudication Thursday, 3:30 p.m.

Chair: $\quad$ Peter W. Sperlich, University of California, Berkeley

SS 37. Comparative Ethnicity Monday, 2:30 p.m.

Chair: Jean Tournon, Universite de Grenoble

SS 38. Global Factors of Democratization Thursday, 10:45 a.m.

Chair: $\quad$ Tatu Vanhanen, University of Tampere

SS 39. Administrative Elites in Britain, France, Greece and the

United States: Recruitment, Training, Role Monday, 9:30 a.m.

Chair: George Vernardakis, Middle Tennessee State University

SS 40. Pre-Post-Apartheid Politics in South Africa:

Getting There from Here Wednesday, 9:30 a.m.

Chairs:

Leon Weaver, Michigan Stote University

Dennis Austin, University of Manchester

SS 4I. Can Soviet Political Culture Be Transformed? Tuesday, 2:30 p.m.

Chair: $\quad$ Robert C. Tucker, Princeton University

SS 42. How Civil Wars End: Cases Tuesday, 9:30 a.m.

Chair: Roy Licklider, Rutgers University

SS 43. Workshop on the Contribution of Political Science to the International Geosphere-Biosphere Program Thursday, 10:45 a.m.

Chair: John E. Trent, University of Ottawa

SS 44. Roundtable on Soviet Politics in a Time of Perestroika Thursday, 1:30 p.m. Chair: Kinhide Mushakoji, United Nations University

SS 45. Toward a Communication Theory of Politics and a Content Oriented Theory of Communication Thursday, 10:45 a.m.

Chair: Karl W. Deutsch, University of Monnheim

SS 46. Cybernetic Modelling and Political Science Thursday, 10:45 a.m.

Chairs:

Miriam L. Campanella, University of Torino Laurence Richards, Old Dominion University 